\title{
The Reaction Of Analysts To Management Disclosures And Firm Characteristics: Conservatism And Corporate Governance
}

\author{
Kyunbeom Jeong, Hansung University, South Korea
}

\begin{abstract}
This paper examines the effect of firm characteristics on analyst reaction to management disclosures. Prior studies have overlooked the fact that analysts can react differently as a result of firm characteristics that can affect the management forecasts' credibility and usefulness, as well as specific situation like SEO or management forecast characteristics itself. This study extends this line of research by considering firm characteristics after controlling for factors with respect to management forecast characteristics that may affect analyst reaction. I provide evidence that good news management disclosures by firms with high levels of conservatism have more impact to the analysts; therefore, analysts react more to good news management disclosures issued by firms with a high level of conservatism than good news management disclosures that are issued by firms with low levels of conservatism. Similarly, the study finds that analysts react less to bad news management disclosure issued by firms with a high level of conservatism. I also find that analysts have a stronger reaction to management disclosures announced by firms with strong governance and a lower level of managerial ownership. These results show that firm characteristics are also factors that are considered by analysts in the revision of their earnings forecasts following management disclosure.
\end{abstract}

Keywords: Accounting Conservatism; Corporate Governance; Management Disclosure; Analyst Forecast Revision

\section{INTRODUCTION}

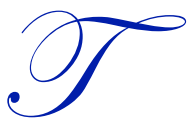

his study examines analyst reactions to management disclosures depending on firm characteristics. Prior studies have shown that analysts have an incentive to issue accurate earnings forecasts (Lim, 2001; Hong and Kubik, 2003) and an incentive to maintain a positive relationship with the firms that they follow (Dugar and Nathan, 1995; Lin and McNichols, 1998). The analyst reaction to management disclosure can be influenced by either of these two incentives. In this manner, Cotter et al. (2006) find that analysts quickly react to management disclosures and are more likely to issue final meetable or beatable earnings targets when management provides public disclosure. Following these studies, analyst reaction to management disclosures has been viewed from differing perspectives. Tan et al. (2010) show that the analyst forecasts reflect management disclosures to a greater extent if the prior management disclosure is accurate. This is because management disclosure that is historically accurate can convince analysts that current management disclosure is more credible than at times of inaccuracy. This study implies that analysts consider manager reputation in their forecasts immediately following the announcement of management disclosures. Additionally, Feng and McVay (2010) provide evidence that analysts consider the disclosures of firms that subsequently announce an equity offering to be more credible because the equity offering provides an incentive to please the firm (ex., underwriter selection). They find specific situations where analysts react differently to management disclosures. These efforts are valuable because they identify certain factors or situations that cause analysts to react differently to management disclosures. However, they examine single characteristics of management disclosures or managers' disclosure pattern individually and did not adopt a whole firm perspective. Therefore, I examine whether the analysts consider the firm characteristics when they reflect management disclosure in their revisions.

To examine the effect of firm characteristics on analyst reaction to management disclosures, I use two types of firm characteristics, accounting conservatism and corporate governance. First, with respect to accounting conservatism, I 
expect that analysts react stronger to management disclosures issued by firms with a greater level of conservatism because such a firm possesses a tendency to disclose their financial information conservatively and the information is also more credible (Kim and Pevzner, 2010). However, the opposite result, analyst reaction to management disclosure is negatively associated with the level of conservatism of the firm, comes out contrary to the prediction. Therefore, this study attempts to determine the results for this outcome by examining the effect using two divided samples, a sample incorporating the disclosure of good news and a sample incorporating the disclosure of bad news. Prior studies suggest that the financial reporting of a conservative firm is more credible; however, conservatism can also bias accounting numbers in a negative direction. Therefore, I predict that the effect can be different depending on whether the disclosure is composed of good news or bad news. Using these divided samples, the results show that with respect to good news disclosures, analysts react greater to the disclosures from firms with greater level of conservatism. However, with respect to bad news disclosures, analysts react less to disclosures from firms with higher level of conservatism. Because of the conflicting results between the two subsamples and the result that analysts react greater to bad news disclosures (Cotter et al., 2006), the result for the total sample is that disclosures from conservative firms result in less reaction from analysts, which is contrary to expectations.

Second, with respect to corporate governance, I use two types of proxy, board independence and managerial ownership. If the level of board independence is high, then presumably the directors are monitoring and providing guidance to ensure that the disclosed information is credible and useful for shareholders. Therefore, analysts are more likely to reflect the disclosures issued by firms with greater board independence in their earnings forecasts. Additionally, higher-level ownership managers, who want to maximize private benefits opportunistically, can withhold information from or manipulate information that is divulged to outside investors or analysts (Baik and Yi, 2007). Thus, disclosures issued by higher-level ownership managers may be less credible, and analysts are less likely to react to these disclosures. I find that the results from this study support these conjectures using governance variables. Overall, this study provides evidence that firm characteristics are considered by analysts in the revision of their earnings forecasts and that the content of the revisions are the result of reactions to management earnings disclosures.

The contributions of this paper are as follows. First, analyst behavior is important because analysts play a crucial role as information providers for financial markets. An examination of analyst behavior reveals the effectiveness of the analyst role and whether the information provided sufficiently reflects the factors that can affect the information's credibility or usefulness. Second, this paper provides evidence that analysts consider and reflect whole firm characteristics in their revised earnings forecasts. This study finds that analysts react differently to management disclosures depending on the firm characteristics such as accounting conservatism, managerial ownership, and corporate governance, in addition to specific situations or management forecast characteristics. The evidence demonstrates that analysts consider management disclosure from a whole firm perspective when they react to the disclosures. Third, with respect to conservatism, a prior study finds that analyst earnings forecasts do not fully impound the implications of accounting conservatism (Pae and Thornton, 2010). However, I provide evidence that analysts understand accounting conservatism and that they consider a firm's conservatism level in their revision of earnings forecasts to some degree. Fourth, the level of detail effect reveals that analysts react to management disclosure depending on the type of news (good news or bad news) and that different types of news are considered differently depending on firm characteristics, especially accounting conservatism, as a result of the nature of conservatism. For conservative firms, good news is indicative of really good news, whereas, for a less conservative firm, good news is not considered to be a positive indicator to the same extent. Depending on the conservatism level of the firm, not all good news is equally good, and not all bad news is equally bad.

This paper proceeds as follows. Section 2 introduces related research and develops the hypotheses. Section 3 explains the sample and research design. Section 4 describes the main results of the hypotheses tests. Section 5 reports the additional analyses, and finally, Section 6 concludes the study.

\section{RELATED RESEARCH AND HYPOTHESES}

Existing studies investigate different analyst reactions depending on the characteristics of management forecasts and the timing of the forecast release. This type of study typically addresses two primary characteristics of management forecasts that affect analyst reaction to forecasts, credibility and usefulness. If the management disclosures are 
considered credible and useful, then analysts credit these disclosures with more weight when revising earnings forecasts. Analysts consider management forecast characteristics, such as credibility and usefulness, when they revise earnings forecasts. Certain prior studies provide evidence that analyst reaction is different depending on the credibility of management forecasts using proxies for the credibility of management forecasts. Hassell et al. (1988), Williams (1996), and Cotter et al. (2006) suggest that if management disclosure is downward disclosure (i.e., bad news), then it is more credible. Managers possess an incentive to overstate current earnings and expectations for future cash flows to reflect efficient management and to maximize their compensation. Therefore, downward disclosure appears more credible because of this management-associated characteristic. Additionally, these studies find that analysts react greater to bad news disclosure. Tan et al. (2010) provide evidence to demonstrate that analysts react greater to management disclosure, if the prior management disclosure accuracy has been high, because the history of prior disclosure accuracy can cause analysts to think that management forecasting of a current period is also credible.

Other papers examine different analyst reactions to management forecasts depending on the usefulness of the forecasts. Baginski et al. (1993) document that the more precise the management disclosure, the more useful it is. Feng and McVay (2010) find that analysts react significantly to precise disclosures and suggest that early disclosure is more useful to analysts because analysts have limited information concerning the earnings of newly established firms, and the management forecasts in this case contain useful information for analysts. They empirically find that analysts credit early management forecasts with significant weight.

The prior literature suggests that analyst reaction to management forecasts differs according to management forecast characteristics. However, these prior studies consider each particular basic characteristic of management forecasting itself using proxies, such as good news and bad news, and not from the whole firm perspective. Can firm characteristics affect management forecast characteristics? If firm characteristics can affect management disclosure characteristics (credibility and usefulness), it may be assumed that firm characteristics may also have an effect on analyst reaction. Analysts have an incentive to react differently depending on the firm characteristics because of the effect of firm characteristics on management forecast credibility or usefulness. Therefore, I investigate the possibility that firm characteristics have an influence on analyst reaction to management disclosure in this study.

Certain firm characteristics can affect management forecasting credibility and usefulness. First, I examine the conservatism level of the firm. A firm's level of conservatism affects the management forecast characteristics. Conservatism forces earlier recognition of bad news that managers have an incentive to delay. Chen et al. (2007) argue that conservatism can reduce upward earnings management by recognizing earnings conservatively. LaFond and Watts (2008) document that conservatism reduces information asymmetry by increasing the speed with which negative information is revealed in the earnings. Management has an incentive, therefore, to overstate accounting earnings; thus, conservatism can render a firm's financial results credible. Analysts can also perceive earnings announcement from conservative firms to be more informative and more credible, like investors (Kim and Pevzner, 2010). These prior studies focus on the role of conservatism with respect to manager earnings announcements. In the case of voluntary management disclosures, it is also true that management forecasts of more conservative firms are less optimistic and more informative. Therefore, I suggest that the management forecasts of conservative firms are more credible and useful and that analysts react more significantly to the management forecasts that are announced by such conservative firms. Therefore, I present Hypothesis 1 . For convenience, I term the coefficient that indicates analyst response to management earnings forecasts the analyst response coefficient (ARC) for management forecasts.

Hypothesis 1: The analyst response coefficient (ARC) for management forecasts is greater for firms with a higher level of conservatism.

I also examine the effects of accounting conservatism on analyst reaction by dividing management forecasts into two groups, good news forecasts and bad news forecasts, because conservatism can affect good news and bad news forecasts differently. When a good news management forecast is announced with respect to a less conservative firm, analysts can perceive this disclosure as less credible because this good news disclosure of a less conservative firm is optimistically biased. However, with respect to a conservative firm, good news disclosure is perceived to be more credible by analysts because good news by a conservative firm is relatively less biased as a result of conservative accounting tendency. Conversely, bad news disclosure by a less conservative firm can be perceived as more credible 
than that of a conservative firm. If a conservative firm issues a good news management forecast, analysts are likely to consider this as really good news, because they are conservative when it comes to recognizing their earnings. Analysts recognize that this good news is released despite conservative reporting behavior and is, therefore, credible, and the analyst reaction is greater in response to a conservative firm's good news disclosure than the disclosure of a less conservative firm. If a conservative firm issues bad news, then this disclosure is deemed bad news of little significance because the tendency of such a firm is to recognize earnings conservatively. A bad news management forecast from a conservative firm is perceived to be lacking in credibility and of little use to analysts. Therefore, I also hypothesize the following depending on the type of management forecast.

Hypothesis 2a: The analyst response coefficient (ARC) for management forecasts is greater in response to good news disclosures from firms with a higher level of conservatism.

Hypothesis 2b: The analyst response coefficient (ARC) for management forecasts is greater in response to bad news disclosures from firms with a lower level of conservatism.

A firm's governance structure is another firm characteristic that affects management forecast characteristics. The board of directors is the main corporate governance mechanism. Fama and Jensen (1983) argue that the board of directors should monitor a firm's management to mitigate the agency conflicts that result from the separation of ownership and control. The board of directors can effectively monitor managers when the directors are independent. Board independence is an indicator of strong governance. How does strong governance, such as an independent board, affect management forecast characteristics? Managers in firms with strong governance are monitored by the governance mechanism, and an independent board monitors the financial reporting process. Beasley (1996) find that a larger proportion of external board directors prevents financial statement fraud because external directors monitor the preparation of financial statements more effectively. Klein (2002) also find that independent boards are more effective in monitoring the financial accounting process and that independent boards prevent earnings management by managers. Additionally, Sengupta (2004) documents that firms with independent boards are likely to announce quarterly earnings earlier. Thus, a firm that possesses an independent board of directors releases useful and credible management forecasts because board pressure is more aligned with the interests of shareholders. Ajinkya et al. (2005) find that firms with external directors are more likely to issue a forecast and that these forecasts tend to be more specific and accurate. These prior studies imply that independent directors cause managers to issue credible and useful forecasts and analyst reaction to these management forecasts is also affected by this firm characteristic. Therefore, I hypothesize that:

Hypothesis 3: The analyst response coefficient (ARC) for management forecasts is greater for firms with a higher level of board independence.

Managerial ownership is another firm characteristic that can also affect management forecast characteristics. Managers are agents that represent shareholders and often experience conflict between their private benefits and those of shareholders. Managers with sufficient ownership often pursue their own wealth to the detriment of shareholder benefits. Shleifer and Vishny (1986) model this problem and show that manager ability to conduct relationshipspecific investments and contracts can cause their replacement to be difficult, which permits them to extract greater wealth. Managers may, therefore, entrench themselves and pursue their own wealth. Morck et al. (1988) document that if managerial ownership is minimal, manager interest might align with external shareholder interest; however, higher levels of managerial ownership can result in greater manager entrenchment and increasing agency costs. From this entrenchment perspective, managers with a higher level of ownership who endeavor to maximize private benefits opportunistically can withhold or manipulate the information released to external investors or analysts (Baik and Yi, 2007). Managers with a higher level of ownership are likely to disclose information that is beneficial to their own interests or to time the release of information opportunistically. Entrenched managers with a higher level of ownership may use management forecasts for their own interests rather than those of the shareholders. Thus, managers with a higher level of ownership may issue less credible and less useful management forecasts because of their opportunistic behavior with respect to management disclosure. Analysts are also not likely to reflect the management forecasts from managers with a higher level of ownership. Therefore, I hypothesize that: 
Hypothesis 4: The analyst response coefficient (ARC) for management forecasts is greater for firms with managers with a lower level of ownership.

\section{SAMPLE AND RESEARCH DESIGN}

\section{Sample and data}

The data for the sample were extracted from the First Call database, which provides management disclosure, analyst forecasting, and actual earnings data, for the period 1995 to 2009. ${ }^{1}$ To measure the level of conservatism, I use the Compustat Annual and CRSP database. I also use CEO and top manager ownership data from the ExecuComp (in Compustat) database, corporate governance data from the Risk Metrics database, and quarterly financial statement data from the Compustat Quarterly database. The total management forecasts observations for this period is 57,848 . I first exclude non-EPS forecasts, non-USD currency forecasts, and qualitative forecasts to measure management disclosure levels and analyst revision levels. Figure 1 illustrates that I also exclude forecasts issued before the date of the earnings announcement of the prior quarter and forecasts issued after the date of the earnings announcement of the current quarter to examine the pure effect of management forecasts on analyst forecast revisions. To calculate management disclosure levels, I exclude observations without preexisting analyst forecasts. For levels of conservatism, ownership, director, and other variables, I exclude observations for which these variables cannot be calculated. After all variables are accounted for, the final sample for empirical analysis is composed of 6,655 observations. ${ }^{2}$ The detailed procedure of sample selection is reported in Table 1.

Figure 1. Timeline and variable measurement

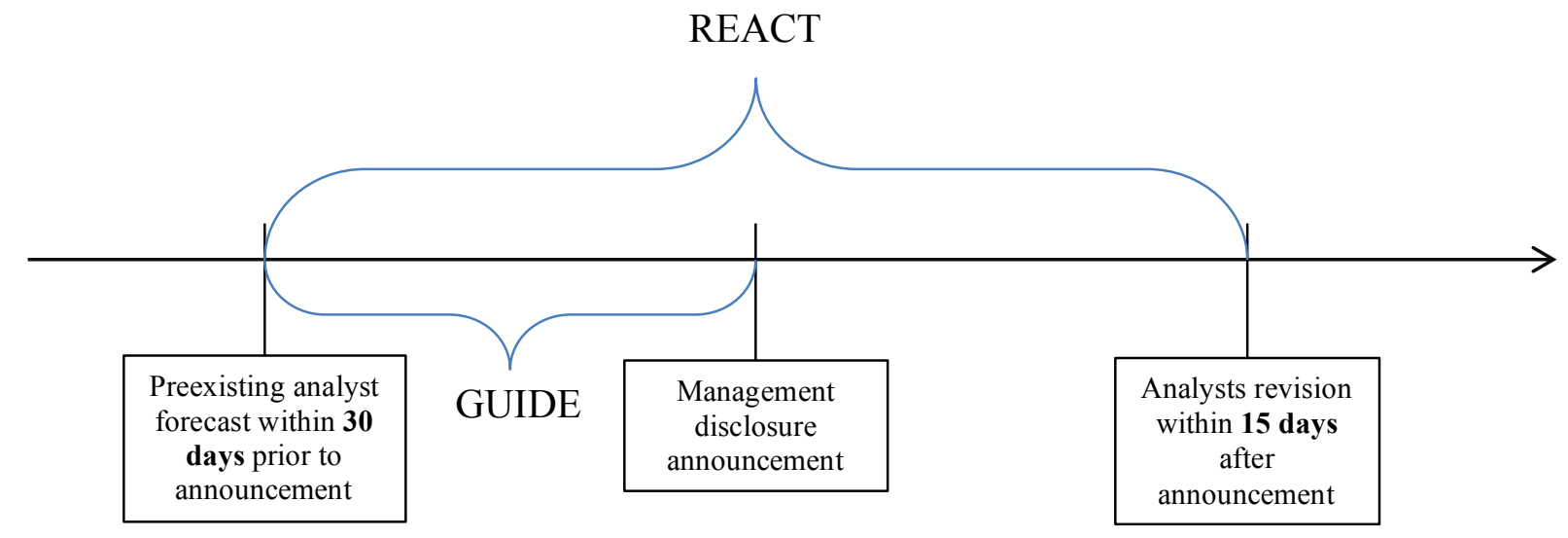

\footnotetext{
${ }^{1}$ As a result of data insufficiency, the sample period is from year 1995 to 2009.

${ }^{2}$ To eliminate outlier problems, I truncate the top and bottom $0.5 \%$ of the same continuous variables. With truncation of $1 \%$ and $2 \%$, the results do not change qualitatively.

Copyright by author(s); $\underline{\mathrm{CC}-\mathrm{BY}}$ 
Table 1. Sample selection procedures

\begin{tabular}{lr}
\hline & Number of Forecasts \\
\hline Total forecasts & 57,848 \\
\hline Less: & 1,783 \\
\hline Non-EPS forecasts & 345 \\
\hline Non-USD currency forecasts & 8,063 \\
\hline Qualitative forecasts & 528 \\
\hline Duplicate forecasts & 122 \\
\hline Forecasts without CUSIPs & 656 \\
\hline Forecasts missing actual earnings data & 5,747 \\
\hline Forecasts issued before the earnings announcement date of the prior quarter & 247 \\
\hline Forecasts issued after the earnings announcement date of the current quarter & 21,017 \\
\hline Observations without analyst preexisting forecasts & 4,114 \\
\hline Insufficient observations for calculating average reputation & 304 \\
\hline Observations without stock price data & 2,543 \\
\hline Observations without conservatism measure data & 3,422 \\
\hline Observations without ownership data & 1,695 \\
\hline Observations without director data & 232 \\
\hline Observations in the financial services industries & 30 \\
\hline Observations without other control variables data & 27 \\
\hline Multiple disclosure issuances (retaining the most recent disclosure) & 318 \\
\hline The top and bottom 1\% of management disclosure, analyst revisions, and conservatism measures & 6,655 \\
\hline Final sample & \\
\hline
\end{tabular}

\section{Research Design and Variable Definitions}

\section{The Empirical Model}

To investigate the reaction of analysts to management disclosure in the revision of earnings forecasts, I estimate the following regression model depending on firm characteristics:

$$
\begin{aligned}
& \text { REACT }=\beta_{0}+\beta_{1} \text { GUIDE }+\beta_{2} \text { GUIDE FIRM_Char }+\beta_{3} \text { GUIDE REPUTATION }+\beta_{4} \\
& \text { GUIDE DOWN }+\beta_{5} \text { GUIDE HORIZON }+\beta_{6} \text { GUIDE RANGE }+\beta_{7} \text { GUIDE ANALYSTS }+\beta_{8} \\
& \text { FIRM_Char }+\beta_{9} \text { REPUTATION }+\beta_{10} D O W N+\beta_{11} \text { HORIZON }+\beta_{12} \text { RANGE }+\beta_{13} \text { ANALYSTS }+\varepsilon .
\end{aligned}
$$

I follow the model used in Feng and McVay (2010) that investigates analyst reaction to management disclosure when revising their forecasts. This current study investigates analyst reaction to management disclosure and the differences depending on firm characteristics. Thus, the research design requires measuring the levels of public disclosure from managers and the subsequent analyst forecast revisions to earnings forecasts. Consistent with Feng and McVay (2010), I first measure the disclosure level of management forecasts (GUIDE) as the difference between the manager earnings forecast and the preexisting median consensus of analyst forecasts scaled by price at the beginning of the quarter. The preexisting consensus analyst forecast is the last revised consensus within 30 days prior to the management disclosure. To measure the analyst reaction level, I set $R E A C T$ as the revised consensus of analyst forecasts minus the preexisting median consensus of analyst forecasts, scaled by price at the beginning of the quarter. The revised consensus is the last revised consensus available within the 15 days following the management disclosure, and, if there is no revision, the preexisting forecast is used as the revised consensus (i.e., reaction is zero). This measure identifies the extent to which the analyst forecasts are revised after the management disclosure is released.

This model investigates the association between management disclosure and analyst reaction. Analysts generally reflect management disclosure when they revise their forecasts; thus, $\beta_{I}$ is expected to be positive. Using proxies for firm characteristics and controls, I calculate the interaction variables with GUIDE because my focus is on whether firm characteristics have an effect on the relationship between management disclosure and the level of analyst forecast revision. The control variables are factors that might affect the relationship between management disclosure levels and the reaction level of analysts. I use all firm characteristics variables at the fiscal year end of the year t- 1 because 
firm characteristics of year $t$ cannot be identified by analysts at the moment that they revise their earnings forecast in reaction to management disclosure in the year $\mathrm{t}$.

\section{The Proxies for Firm Characteristics}

This study investigates the effect of firm characteristics on analyst reaction to management disclosure. First, the independent variable $F I R M$ char uses five measures including accounting conservatism $(C O N)$, ownership measures (CEO_OWN, TOP_OWN), and board independence measures (B_INDEP, AC_INDEP). With respect to the measures for conservatism, $\overline{\mathrm{I}}$ apply three types of individual measures (one representing conditional conservatism and two representing unconditional conservatism) and two types of aggregate measures representing the validity and the credibility of the proxies.

The first measure of conservatism is CSCORE, following Khan and Watts (2009). Specifically, it is calculated by the following annual, cross-sectional regression model:

$$
\begin{aligned}
& X_{i}=\beta_{1}+\beta_{2} D_{i}+R_{i}\left(\mu_{1}+\mu_{2} \text { Size }_{i}+\mu_{3} M / B_{i}+\mu_{4} \text { Lev }_{i}\right)+D_{i} R_{i}\left(\lambda_{1}+\lambda_{2} \text { Size }_{i}+\lambda_{3} M / B_{i}+\lambda_{4} \text { Lev }_{i}\right) \\
& +\left(\delta_{1} \text { Size }_{i}+\delta_{2} M / B_{i}+\delta_{3} \text { Lev }_{i}+\delta_{4} D_{i} \text { Size }_{i}+\delta_{5} D_{i} M / B_{i}+\delta_{6} D_{i} \text { Lev }_{i}\right)+\varepsilon_{i}
\end{aligned}
$$

From this regression model, the result is $\mu_{j, t}$ and $\lambda_{\mathrm{j}, \mathrm{t}}(\mathrm{j}=1-4)$ and, using these, I can calculate the incremental timeliness of bad news each year.

The second measure of conservatism is CONACC, based on Givoly and Hayn (2000). This measure is derived from the concept that conservative accounting generates consistently negative accruals by accelerating bad news and decelerating good news. To compute this measure, I first calculate the values of total accruals (income before extraordinary items - cash flows from operations + depreciation expense) deflated by average total assets. I then take the mean over three years, centered on year t. By averaging the values, I can reduce the possible temporary effects on accruals because these transient effects are likely to disappear within two years (Richardson et al., 2005). I then multiply by negative one (-1) so that a larger value of the measure implies a greater level of conservatism.

The third measure of conservatism is CONBM. Generally, conservative firms tend to understate the book value of equity compared to the market value of equity. For this reason, conservative firms will have a lower book-to-market ratio. I calculate $C O N B M$ as the book-to-market ratio multiplied by negative one (-1) because a higher value for the measure should indicate a higher level of conservatism (Beaver and Ryan, 2000).

The other two measures of conservatism are CONAGG1 and CONAGG2. Following the concept used in Hui et al. (2009), I develop two aggregate measures because each of the three measures above contains some errors in gauging the level of conservatism. First, I calculate the rank of each firm's conservatism level based on CSCORE, CONACC, and CONBM. CONAGG1 is the average value of these three ranks regardless of whether the measures indicate conditional or unconditional conservatism, and CONAGG2 is the average value of two ranks of unconditional conservatism measures (i.e., CONACC and CONBM). I adopt the mean of the rank values because the mean of the raw values might be biased by a dominant or extreme value. However, this method using the rank values may mitigate these possible biases.

I examine board independence as a corporate governance mechanism. I use $B_{-} I N D E P$ as a proxy for board independence, which is defined as the percentage of independent directors that belong to the full board of directors. This study uses two measures with respect to ownership, CEO_OWN and TOP_OWN. CEO_OWN represents the percentage of total shares held by the CEO to total outstanding shares, and TOP_OWN is the percentage of total shares held by the top five executives to total outstanding shares. This study uses CEO and top manager ownership measures as a firm characteristic because $\mathrm{CEO}$ or top manager-related factors can become an area of focus for analysts reacting to management disclosure. 


\section{Other Control Variables}

With respect to control variables, I first use two proxies for credibility that have already been used in prior literature, $D O W N$ and REPUTATION. These proxies can directly affect the credibility of management forecasts. $D O W N$ is an indicator variable that equals 1 if the manager's disclosure is a downward disclosure (i.e., the management forecast is lower than the preexisting consensus of analyst forecasts) (e.g., Hassell et al. 1988; Cotter et al. 2006). Because managers possess an incentive to overstate the current financial situation to imply superior management and to maximize compensation, management disclosure may appear credible if it is a downward disclosure. REPUTATION is the average accuracy of management disclosure for the prior three years, where the accuracy is equal to 1,0 , and 1 if the absolute value of the management forecast error is less than, equal to, and greater than the preexisting analyst forecast error, respectively. Therefore, REPUTATION is higher when the historical reputation of the management is superior. If historical reputation is superior in terms of management forecasting, then the likelihood that the current management forecast is accurate is also considered to be high (Tan et al., 2010).

I also control for factors that can affect the usefulness of management disclosure, HORIZON and RANGE. HORIZON is the log of the number of days between the release date of management disclosure and the earnings announcement. If the number of days is low, limited information is available in the market, and the usefulness of management disclosure is high if HORIZON is high. RANGE measures the management disclosure precision by calculating the range of the forecast scaled by the stock price at the beginning of the quarter for a range forecast and 0 for a point forecast. If the management disclosure range is higher, the usefulness of the disclosure is lower. Additionally, I use ANALYSTS as a control variable for the log of the number of analysts following a firm because I use the measures based on the consensus analyst forecast.

\section{RESULTS}

\section{Descriptive Statistics}

Table 2 presents the descriptive statistics of variables that are used in this study. The mean of REACT and GUIDE are -0.0012 and -0.0002 , respectively, which are comparable to those reported in Feng and McVay (2010). The mean values of conservatism measures, CSCORE, CONACC, and CONBM are 0.0554, 0.0175, and -0.4333, respectively. The mean of CSCORE is lower than that reported in Khan and Watts (2009), but this may be because the sample period used by Khan and Watts (2009) differs from my sample. Including CSCORE, other measures of conservatism are consistent with those in prior literature with slight variations (Ahmed and Duellman, 2007; Krishnan and Visvanathan, 2008). With respect to ownership, CEO has, on average, approximately $1.73 \%$ and the top five managers have approximately $2.68 \%$ of total shares outstanding. For the $D O W N$ variable, the mean value is 0.4972 ; this implies that the downward disclosure relative to the preexisting consensus of analyst forecasts is approximately $50 \%$ percent of the total management disclosure contained in the sample.

The correlation coefficients for the independent and the dependent variables are untabulated. In the untabulated results, I find that the correlation between REACT and GUIDE is significantly positive. The majority of the correlations between conservatism measures and REACT are positive and significant with the exception of CSCORE and REACT. The ownership variables are negatively correlated with $R E A C T(-0.028,-0.020)$, and the board independence variables are positively correlated with the analyst reaction variable $(0.016,0.000)$. 
Table 2. Descriptive statistics

\begin{tabular}{l|r|l|r|r|r|r|r}
\hline \multicolumn{1}{c|}{ Variable } & Mean & Std.Dev & Median & Min. & $\mathbf{2 5 \%}$ & $\mathbf{7 5 \%}$ & Max. \\
\hline REACT & -0.0012 & 0.0040 & 0.0000 & -0.0413 & -0.0015 & 0.0002 & 0.0098 \\
\hline GUIDE & -0.0002 & 0.0063 & 0.0000 & -0.0996 & -0.0015 & 0.0015 & 0.0266 \\
\hline CSCORE & 0.0554 & 0.0876 & 0.0710 & -0.4375 & 0.0202 & 0.1105 & 0.4293 \\
\hline CONACC & 0.0175 & 0.0400 & 0.0129 & -0.1381 & -0.0047 & 0.0339 & 0.2559 \\
\hline CONBM & -0.4333 & 0.2501 & -0.3738 & -1.8135 & -0.5506 & -0.2558 & -0.0679 \\
\hline CONAGG1 & 3.3280 & 0.9588 & 3.3093 & 0.4243 & 2.6343 & 4.0178 & 6.4640 \\
\hline CONAGG2 & 3.3280 & 1.3796 & 3.2995 & 0.1365 & 2.3160 & 4.2920 & 6.5650 \\
\hline CEO_OWN & 0.0173 & 0.0421 & 0.0028 & 0.0000 & 0.0009 & 0.0097 & 0.3466 \\
\hline TOP_OWN & 0.0268 & 0.0527 & 0.0068 & 0.0001 & 0.0025 & 0.0206 & 0.3903 \\
\hline B_INDEP & 0.7003 & 0.1595 & 0.7143 & 0.1111 & 0.6000 & 0.8333 & 1.0000 \\
\hline AC_INDEP & 0.9302 & 0.1596 & 1.0000 & 0.0000 & 1.0000 & 1.0000 & 1.0000 \\
\hline DOWN & 0.4972 & 0.5000 & 0.0000 & 0.0000 & 0.0000 & 1.0000 & 1.0000 \\
\hline REPUTATION & 0.0122 & 0.6823 & 0.0000 & -1.0000 & -0.6000 & 0.5556 & 1.0000 \\
\hline HORIZON & 3.9953 & 0.7736 & 4.4308 & 0.0000 & 3.5553 & 4.5109 & 6.7957 \\
\hline RANGE & 0.0014 & 0.0017 & 0.0009 & 0.0000 & 0.0004 & 0.0018 & 0.0386 \\
\hline ANALYSTS & 2.2912 & 0.5899 & 2.3026 & 0.0000 & 1.9459 & 2.7081 & 3.5835 \\
\hline
\end{tabular}

The sample includes 6,655 observations from 1995 to 2009. The variable definitions are presented in the Appendix.

\section{Results for Conservatism}

The Results for the Tests of Hypothesis 1

Table 3 reports the results of the estimation of equation (1) for each five measures of conservatism. I hypothesize that the ARC for management forecasts is positive for those firms that exhibit higher levels of conservatism. To be consistent with Hypothesis $1, \beta_{2}$ should be positive; however, the results show that the coefficient of the interaction variable $G U I D E^{*} C O N$ is significantly negative across all five measures of conservatism. The result implies that analyst reaction is greater in response to management forecasts from firms with lower levels of conservatism, which is contrary to my prediction. I defer the explanation of these results to the next subsample analysis section. The coefficients of the GUIDE*DOWN and GUIDE*REPUTATION variables are significantly positive for all measures of conservatism. This implies that analyst reaction is greater in response to downward management forecasts and to the management forecasts from firms with a higher level of historical management forecast accuracy, which is consistent with my prediction and those of prior studies. Additionally, I find that analysts lend more weight to the disclosure when the range of management disclosure is greater and more analysts follow the firm. 
Table 3. Revision magnitude on conservatism (Full sample, Dependent variable $=$ REACT)

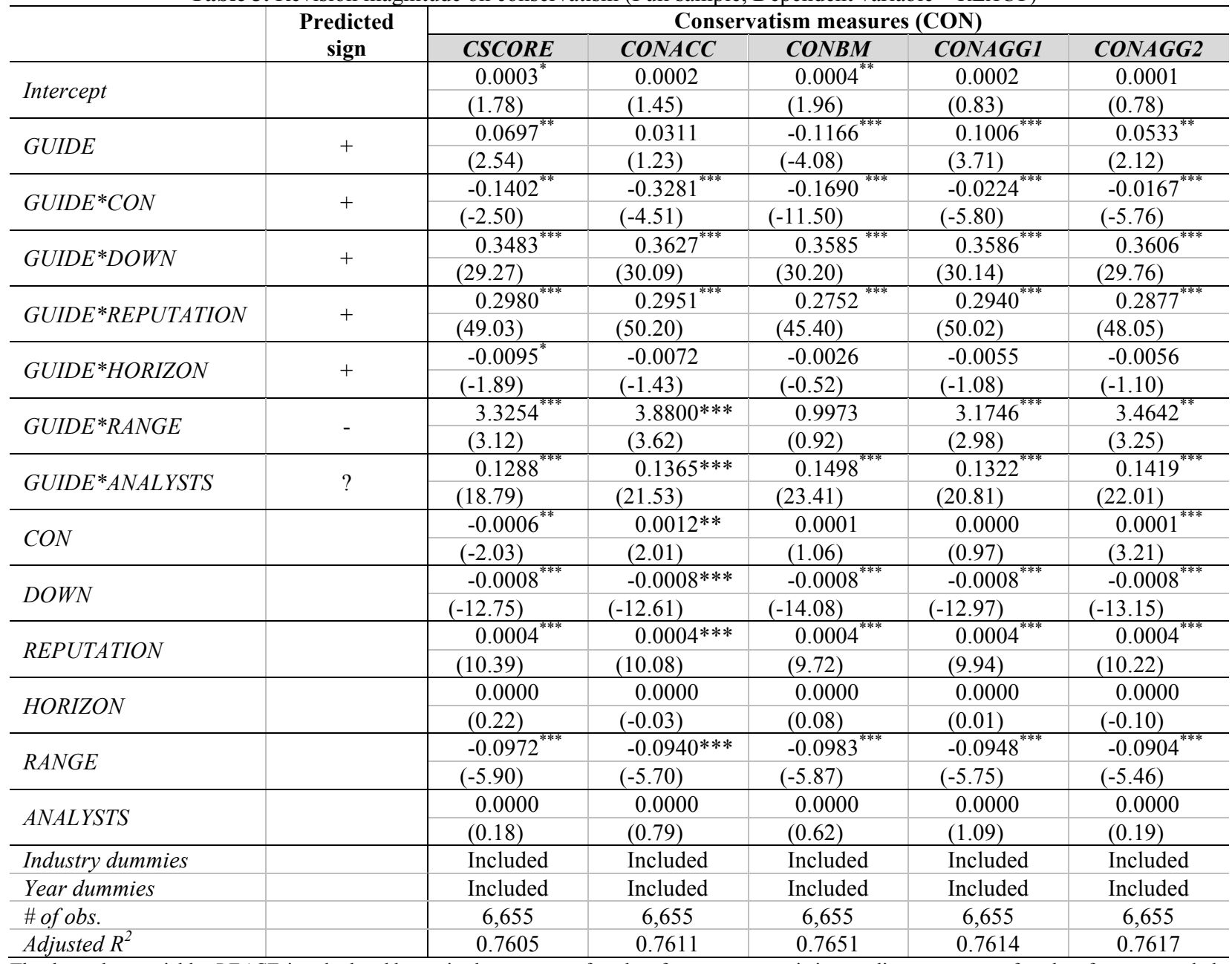

The dependent variable, REACT, is calculated by revised consensus of analyst forecasts - preexisting median consensus of analyst forecasts scaled by price at the beginning of the quarter. Other detailed variable definitions are presented in the Appendix.

$*, * *$, and $* * *$ indicate two-tailed significance at the $0.10,0.05$, and 0.01 levels, respectively.

The Results for the Tests of Hypotheses $2 a$ and $2 b$

To perform further analyses, I divide the sample into two groups according to whether the management forecasts are downward or upward disclosures. The results of the tests using these subsamples are presented in Table 4. Using the good news disclosure sample and five conservatism measures that I used in the full sample analysis shown in panel $\mathrm{A}$, the results for the majority of the conservatism measures are that analyst reactions are significantly and positively associated with levels of conservatism. This implies that analyst reaction is greater in response to good news from firms with a higher level of conservatism, which is consistent with Hypothesis 2a. Similarly, the results in panel B support Hypothesis $2 \mathrm{~b}$ and show negative coefficients of GUIDE*CON across all measures of conservatism. Therefore, according to the type of management disclosure, conservatism affects analyst reaction. The results of the full sample may be found by summing up these two opposite effects of conservatism. However, the effects of downward disclosures are dominant because analysts lend more credibility to downward disclosures (e.g., Williams, 1996). Thus, the full sample results can be explained by the dominant effects of conservatism on downward management disclosures. The coefficients of the control variables are similar to the full sample analysis results with the exception of the significance level. 
Table 4. Revision magnitude on conservatism (Good vs. Bad news disclosure)

\begin{tabular}{|c|c|c|c|c|c|c|}
\hline \multicolumn{7}{|c|}{ Panel A. Good news disclosure $($ Dependent variable $=R E A C T)$} \\
\hline & \multirow{2}{*}{$\begin{array}{c}\text { Predicted } \\
\text { sign }\end{array}$} & \multicolumn{5}{|c|}{ Conservatism measures $(\mathrm{CON})$} \\
\hline & & CSCORE & CONACC & CONBM & CONAGG1 & CONAGG2 \\
\hline \multirow{2}{*}{ Intercept } & & 0.0003 & $0.0003^{*}$ & -0.0001 & $0.0005^{* *}$ & $0.0004^{*}$ \\
\hline & & $(1.53)$ & $(1.75)$ & $(-0.53)$ & $(2.46)$ & $(1.95)$ \\
\hline \multirow{2}{*}{$G U I D E$} & \multirow{2}{*}{+} & 0.3776 & $0.3553^{* * *}$ & $0.4287^{* * *}$ & $0.3094^{* * *}$ & $0.3344^{* * *}$ \\
\hline & & $(10.51)$ & $(10.57)$ & $(11.39)$ & $(8.21)$ & $(9.80)$ \\
\hline \multirow{2}{*}{$G U I D E^{*} C O N$} & \multirow{2}{*}{+} & $-0.1136^{*}$ & $0.3952^{* * *}$ & $0.0999^{* * *}$ & $0.0150^{* * *}$ & $0.0156^{* * *}$ \\
\hline & & $(-1.65)$ & $(3.02)$ & $(4.62)$ & $(2.79)$ & $(4.12)$ \\
\hline \multirow{2}{*}{ GUIDE*REPUTATION } & \multirow{2}{*}{+} & $0.2966^{* * *}$ & $0.2918^{* * *}$ & $0.3025^{* * *}$ & $0.2972^{* * *}$ & $0.2969^{* * *}$ \\
\hline & & $(29.54)$ & $(28.92)$ & $(29.94)$ & $(29.63)$ & $(29.63)$ \\
\hline \multirow{2}{*}{ GUIDE*HORIZON } & \multirow{2}{*}{+} & $-0.0268^{* * *}$ & $-0.0243^{* * *}$ & $-0.0281^{* * *}$ & $-0.0268^{* * *}$ & $-0.0269^{* * *}$ \\
\hline & & $(-4.19)$ & $(-3.79)$ & $(-4.40)$ & $(-4.19)$ & $(-4.21)$ \\
\hline \multirow{2}{*}{$G U I D E * R A N G E$} & \multirow[b]{2}{*}{-} & 4.9690 & 4.6800 & $7.0895^{* *}$ & 5.5044 & 6.4719 \\
\hline & & $(1.44)$ & $(1.37)$ & $(2.05)$ & $(1.60)$ & $(1.87)$ \\
\hline \multirow{2}{*}{ GUIDE*ANALYSTS } & \multirow{2}{*}{$?$} & 0.0070 & 0.0069 & 0.0039 & 0.0124 & 0.0023 \\
\hline & & $(0.71)$ & $(0.75)$ & $(0.41)$ & $(1.36)$ & $(0.24)$ \\
\hline \multirow{2}{*}{$C O N$} & & 0.0000 & 0.0009 & $-0.0006^{* * *}$ & -0.0001 & $0.0000^{*}$ \\
\hline & & $(0.15)$ & $(1.20)$ & $(-4.84)$ & $(-2.19)$ & $(-1.94)$ \\
\hline \multirow{2}{*}{ REPUTATION } & & $0.0002^{* * *}$ & $0.0002^{* * *}$ & $0.0002^{* * *}$ & $0.0002^{* * *}$ & $0.0002^{* * *}$ \\
\hline & & $(4.56)$ & $(4.79)$ & $(3.80)$ & $(4.50)$ & $(4.66)$ \\
\hline \multirow{2}{*}{ HORIZON } & & 0.0000 & 0.0000 & 0.0000 & 0.0000 & 0.0000 \\
\hline & & $(-0.74)$ & $(-0.96)$ & $(-0.49)$ & $(-0.70)$ & $(-0.68)$ \\
\hline \multirow{2}{*}{$R A N G E$} & & -0.0059 & -0.0069 & -0.0281 & -0.0097 & -0.0124 \\
\hline & & $(-0.28)$ & $(-0.33)$ & $(-1.30)$ & $(-0.46)$ & $(-0.58)$ \\
\hline \multirow{2}{*}{ ANALYSTS } & & 0.0000 & 0.0000 & $0.0001^{*}$ & 0.0000 & 0.0001 \\
\hline & & $(0.80)$ & $(0.73)$ & $(1.95)$ & $(0.82)$ & $(1.35)$ \\
\hline Industry dummies & & Included & Included & Included & Included & Included \\
\hline Year dummies & & Included & Included & Included & Included & Included \\
\hline \# of obs. & & 3,346 & 3,346 & 3,346 & 3,346 & 3,346 \\
\hline Adjusted $R^{2}$ & & 0.3353 & 0.3391 & 0.3401 & 0.3361 & 0.3379 \\
\hline
\end{tabular}

The dependent variable, REACT, is calculated by revised consensus of analyst forecasts - preexisting median consensus of analyst forecasts scaled by price at the beginning of the quarter.

Other detailed variable definitions are presented in the Appendix.

All regressions control the industry and year fixed effect.

$*, * *$, and $* * *$ indicate two-tailed significance at the $0.10,0.05$, and 0.01 levels, respectively.

(Table 4, Panel B continued on text page) 
(Table 4 continued)

Panel B. Bad news disclosure $($ Dependent variable $=R E A C T)$

\begin{tabular}{|c|c|c|c|c|c|c|}
\hline & \multirow{2}{*}{$\begin{array}{l}\text { Predicted } \\
\text { sign }\end{array}$} & \multicolumn{5}{|c|}{ Conservatism measures (CON) } \\
\hline & & CSCORE & CONACC & CONBM & CONAGG1 & CONAGG2 \\
\hline \multirow{2}{*}{ Intercept } & & $-0.0027^{* * *}$ & $-0.0031^{* * *}$ & $-0.0038^{* * *}$ & $-0.0029^{* * *}$ & $-0.0031^{* * *}$ \\
\hline & & $(-7.35)$ & $(-8.91)$ & $(-10.30)$ & $(-7.46)$ & $(-8.94)$ \\
\hline \multirow{2}{*}{ GUIDE } & \multirow[t]{2}{*}{+} & $0.1838^{* * *}$ & $0.1034^{* *}$ & $-0.1833^{* * *}$ & $0.2142^{* * *}$ & $0.1370^{* * *}$ \\
\hline & & $(4.09)$ & $(2.49)$ & $(-3.90)$ & $(4.84)$ & $(3.32)$ \\
\hline \multirow{2}{*}{$G U I D E^{*} C O N$} & \multirow[t]{2}{*}{-} & $-0.3500^{* * *}$ & $-0.5524^{* * *}$ & $-0.3133^{* * *}$ & $-0.0382^{* * *}$ & $-0.0322^{* * * *}$ \\
\hline & & $(-3.37)$ & $(-4.82)$ & $(-12.42)$ & $(-5.61)$ & $(-6.03)$ \\
\hline \multirow{2}{*}{ GUIDE* REPUTATION } & \multirow[t]{2}{*}{+} & $0.3005^{* * *}$ & $0.2874^{* * *}$ & $0.2519^{* * *}$ & $0.2886^{* * *}$ & $0.2721^{* * *}$ \\
\hline & & $(29.69)$ & $(30.74)$ & $(26.38)$ & $(30.92)$ & $(28.23)$ \\
\hline \multirow{2}{*}{ GUIDE*HORIZON } & \multirow[t]{2}{*}{+} & 0.0108 & $0.0185^{*}$ & $0.0306^{* * *}$ & $0.0236^{* *}$ & $0.0250^{* *}$ \\
\hline & & $(1.13)$ & $(1.91)$ & $(3.25)$ & $(2.41)$ & $(2.55)$ \\
\hline \multirow{2}{*}{$G U I D E^{*} R A N G E$} & \multirow[t]{2}{*}{-} & 0.4017 & 1.7938 & $-4.8314^{* * *}$ & 0.2698 & 0.6834 \\
\hline & & $(0.24)$ & $(1.07)$ & $(-2.86)$ & $(0.16)$ & $(0.42)$ \\
\hline \multirow{2}{*}{ GUIDE*ANALYSTS } & \multirow[t]{2}{*}{$?$} & $0.2188^{* * *}$ & $0.2382^{* * *}$ & $0.2652^{* * *}$ & $0.2282^{* * *}$ & $0.2483^{* * *}$ \\
\hline & & $(18.29)$ & $(22.31)$ & $(24.84)$ & $(21.18)$ & $(22.87)$ \\
\hline \multirow{2}{*}{$C O N$} & & $-0.0020^{* * *}$ & $-0.0020^{*}$ & $-0.0008^{* * *}$ & $-0.0001^{*}$ & 0.0000 \\
\hline & & $(-3.17)$ & $(-1.73)$ & $(-3.71)$ & $(-1.74)$ & $(-0.56)$ \\
\hline \multirow{2}{*}{ REPUTATION } & & $0.0006^{* * *}$ & $0.0006^{* * *}$ & $0.0005^{* * *}$ & $0.0006^{* * *}$ & $0.0005^{* * *}$ \\
\hline & & $(7.86)$ & $(7.24)$ & $(6.19)$ & $(7.32)$ & $(6.76)$ \\
\hline \multirow{2}{*}{ HORIZON } & & $0.0002^{* * *}$ & $0.0002^{* * *}$ & $0.0003^{* * *}$ & $0.0002^{* * *}$ & 0.0002 \\
\hline & & $(2.72)$ & $(2.94)$ & $(3.69)$ & $(3.18)$ & $(3.21)$ \\
\hline \multirow{2}{*}{$R A N G E$} & & $-0.1617^{* * *}$ & $-0.1456^{* * *}$ & $-0.1965^{* * *}$ & $-0.1570^{* * *}$ & $-0.1524^{* * * *}$ \\
\hline & & $(-5.56)$ & $(-4.96)$ & $(-6.69)$ & $(-5.40)$ & $(-5.24)$ \\
\hline \multirow{2}{*}{ ANALYSTS } & & $0.0007^{* * *}$ & $0.0009^{* * * *}$ & $0.0009^{* * *}$ & $0.0008^{* * *}$ & $0.0009^{* * *}$ \\
\hline & & $(8.07)$ & $(10.20)$ & $(10.95)$ & $(9.98)$ & $(9.83)$ \\
\hline Industry dummies & & Included & Included & Included & Included & Included \\
\hline Year dummies & & Included & Included & Included & Included & Included \\
\hline \# of obs. & & 3,309 & 3,309 & 3,309 & 3,309 & 3,309 \\
\hline Adjusted $R^{2}$ & & 0.7568 & 0.7574 & 0.7678 & 0.7581 & 0.7590 \\
\hline
\end{tabular}

The dependent variable, $R E A C T$, is calculated by revised consensus of analyst forecasts - preexisting median consensus of analyst forecasts scaled by price at the beginning of the quarter.

Other detailed variable definitions are presented in the Appendix.

All regressions control the industry and year fixed effect.

$*, * *$, and $* * *$ indicate two-tailed significance at the $0.10,0.05$, and 0.01 levels, respectively.

\section{Results for Corporate Governance}

The results for corporate governance are presented in Table 5. The first column shows the result for the board independence variable, and the last two columns present the results for the ownership variables. In the first column, consistent with Hypothesis 3, I find a significantly positive relationship between the analyst reaction to management disclosure and board independence at the $1 \%$ significance level. I conclude that analysts lend more credibility to management disclosures that are announced by firms with a higher level of board independence in the revising of earnings forecasts. Similarly, I find that a firm's managerial ownership is significant (at the $1 \%$ level) and negatively related to analyst reaction following management disclosures, which is presented in the second and third columns of Table 5. These results support that analysts lend credibility to disclosures when firm managers have a lower level of ownership, which is consistent with Hypothesis 4. Other variables are similar to those reported in previous tables. 
Table 5. Revision magnitude on corporate governance (Dependent variable $=R E A C T)$

\begin{tabular}{|c|c|c|c|c|}
\hline & \multirow{2}{*}{ Predicted sign } & \multicolumn{3}{|c|}{ Corporate governance measures $(\mathrm{GOV})$} \\
\hline & & B_INDEP & CEO_OWN & TOP_OWN \\
\hline \multirow{2}{*}{ Intercept } & & 0.0000 & $0 . \overline{0} 002$ & $0 . \overline{0} 002$ \\
\hline & & $(-0.12)$ & $(1.20)$ & $(1.28)$ \\
\hline \multirow{2}{*}{ GUIDE } & \multirow{2}{*}{+} & -0.0352 & $0.1354^{* * *}$ & $0.2015^{* * *}$ \\
\hline & & $(-1.24)$ & $(5.15)$ & $(7.47)$ \\
\hline \multirow{2}{*}{$G U I D E^{*} G O V$} & \multirow{2}{*}{$+1-$} & $0.1503^{* * *}$ & $-0.0002^{* * *}$ & $-0.0003^{* * *}$ \\
\hline & & $(5.96)$ & $(-11.39)$ & $(-15.04)$ \\
\hline \multirow{2}{*}{$G U I D E * D O W N$} & \multirow{2}{*}{+} & $0.3561^{* * *}$ & $0.3561^{* * *}$ & $0.3627^{* * *}$ \\
\hline & & $(30.07)$ & $(30.34)$ & $(31.08)$ \\
\hline \multirow{2}{*}{ GUIDE*REPUTATION } & \multirow{2}{*}{+} & $0.2886^{* * *}$ & $0.2937^{* * *}$ & $0.2851^{* * *}$ \\
\hline & & $(48.42)$ & $(50.35)$ & $(48.91)$ \\
\hline \multirow{2}{*}{ GUIDE*HORIZON } & \multirow{2}{*}{+} & $-0.0131^{* * *}$ & -0.0069 & $-0.0097^{* *}$ \\
\hline & & $(-2.60)$ & $(-1.38)$ & $(-1.96)$ \\
\hline \multirow{2}{*}{$G U I D E * R A N G E$} & \multirow{2}{*}{-} & $2.5957^{* *}$ & $4.2095^{* * *}$ & $4.1902^{* * *}$ \\
\hline & & $(2.43)$ & $(3.97)$ & $(3.99)$ \\
\hline \multirow{2}{*}{ GUIDE*ANALYSTS } & \multirow[b]{2}{*}{$?$} & $0.1299^{* * *}$ & $0.1219^{* * *}$ & $0.1104^{* * *}$ \\
\hline & & $(20.30)$ & $(19.08)$ & $(17.09)$ \\
\hline \multirow{2}{*}{$G O V$} & & $0.0004^{* *}$ & 0.0000 & 0.0000 \\
\hline & & $(2.51)$ & $(-0.17)$ & $(-0.46)$ \\
\hline \multirow{2}{*}{$D O W N$} & & $-0.0008^{* * *}$ & $-0.0007^{* * *}$ & $-0.0007^{* * *}$ \\
\hline & & $(-12.62)$ & $(-12.62)$ & $(-12.48)$ \\
\hline \multirow{2}{*}{ REPUTATION } & & $0.0004^{* * *}$ & $0.0004^{* * *}$ & $0.0004^{* * *}$ \\
\hline & & $(10.29)$ & $(10.47)$ & $(10.54)$ \\
\hline \multirow{2}{*}{ HORIZON } & & 0.0000 & 0.0000 & 0.0000 \\
\hline & & $(0.02)$ & $(0.09)$ & $(-0.04)$ \\
\hline \multirow{2}{*}{$R A N G E$} & & $-0.1024^{* * *}$ & $-0.0972^{* * *}$ & $-0.0969^{* * *}$ \\
\hline & & $(-6.23)$ & $(-5.96)$ & $(-5.98)$ \\
\hline \multirow{2}{*}{ ANALYSTS } & & 0.0000 & 0.0001 & 0.0001 \\
\hline & & $(0.90)$ & $(1.19)$ & $(1.34)$ \\
\hline \# of obs. & & 6,655 & 6,655 & 6,655 \\
\hline Adjusted $R^{2}$ & & 0.7616 & 0.7647 & 0.7680 \\
\hline
\end{tabular}

The dependent variable, REACT, is calculated by revised consensus of analyst forecasts - preexisting median consensus of analyst forecasts scaled by price at the beginning of the quarter.

Other detailed variable definitions are presented in the Appendix.

All regressions control the industry and year fixed effect.

$*, * *$, and $* * *$ indicate two-tailed significance at the $0.10,0.05$, and 0.01 levels, respectively.

\section{ADDITIONAL TESTS}

\section{Alternative Measures for Corporate Governance}

To test for the effects of corporate governance on analyst reaction to management disclosure, I use a board independence measure and two managerial ownership measures. To check for robustness, I re-examine the corporate governance tests using alternative governance measures, INST_OWN and CEO_CHAIR_SEP. The measure INST_OWN represents institutional ownership measured as a percentage of total shares that are held by institutions to total outstanding shares. The measure CEO_CHAIR_SEP indicates whether the CEO of the firm is also the chair of the board, and it is measured as 1 if the $\mathrm{CEO}$ is not the chair of the board and 0 otherwise. The results for the tests of the effects of corporate governance using these two alternative measures are documented in Table 6 . The results show that the greater the institutional ownership, the greater the impact on analyst reaction to management disclosures because the shareholders possess a powerful monitoring role. The results also show that if the CEO of the firm is not the chair of the board, then analyst reaction is greater in response to management disclosures issued from the firm. This is because if the CEO of the firm also has a role as chair of the board, then the board member monitoring activities will be restricted by the CEO. These results further confirm my predictions concerning corporate governance. 
Table 6. Alternative measures of corporate governance $($ Dependent variable $=R E A C T)$

\begin{tabular}{|c|c|c|c|}
\hline & \multirow{2}{*}{$\begin{array}{l}\text { Predicted } \\
\text { sign }\end{array}$} & \multicolumn{2}{|c|}{ Corporate governance measures $(\mathrm{GOV})$} \\
\hline & & INST_OWN & CEO_Chair_Sep \\
\hline \multirow{2}{*}{ Intercept } & & $0.0017^{* * *}$ & $0.0015^{\text {*** }}$ \\
\hline & & $(5.93)$ & $(5.93)$ \\
\hline \multirow{2}{*}{$G U I D E$} & \multirow{2}{*}{+} & $0.0784^{* * *}$ & $0.1204^{* * *}$ \\
\hline & & $(2.67)$ & $(4.86)$ \\
\hline \multirow{2}{*}{$G U I D E^{*} G O V$} & \multirow{2}{*}{+} & $0.1005^{* * *}$ & $0.0579^{* * *}$ \\
\hline & & $(4.19)$ & $(7.37)$ \\
\hline \multirow{2}{*}{$G U I D E * D O W N$} & \multirow[b]{2}{*}{+} & $0.6261^{* * *}$ & $0.6296^{* * *}$ \\
\hline & & $(47.7)$ & $(48.14)$ \\
\hline \multirow{2}{*}{ GUIDE*REPUTATION } & \multirow{2}{*}{+} & $0.1768^{* * *}$ & $0.1806^{* * *}$ \\
\hline & & $(25.89)$ & $(26.64)$ \\
\hline \multirow{2}{*}{ GUIDE*HORIZON } & \multirow{2}{*}{+} & 0.0032 & 0.0028 \\
\hline & & $(0.65)$ & $(0.56)$ \\
\hline \multirow{2}{*}{$G U I D E * R A N G E$} & \multirow{2}{*}{-} & $4.1312^{* * *}$ & $3.9250^{* * *}$ \\
\hline & & $(2.86)$ & $(2.73)$ \\
\hline \multirow{2}{*}{ GUIDE*ANALYSTS } & \multirow{2}{*}{$?$} & $0.0227^{* * *}$ & $0.0252^{* * *}$ \\
\hline & & $(3.37)$ & $(3.77)$ \\
\hline \multirow{2}{*}{$G O V$} & & $-0.0003^{* *}$ & $-0.0001^{*}$ \\
\hline & & $(-2.25)$ & $(-1.92)$ \\
\hline \multirow{2}{*}{$D O W N$} & & -0.0004 & $-0.0004^{* * * *}$ \\
\hline & & $(-7.80)$ & $(-7.65)$ \\
\hline \multirow{2}{*}{ REPUTATION } & & $0.0004^{* * *}$ & $0.0004^{* * * *}$ \\
\hline & & $(12.87)$ & $(12.60)$ \\
\hline \multirow{2}{*}{ HORIZON } & & $-0.0001^{* * *}$ & $-0.0001^{* * *}$ \\
\hline & & $(-3.30)$ & $(-3.45)$ \\
\hline \multirow{2}{*}{$R A N G E$} & & -0.0190 & -0.0113 \\
\hline & & $(-1.27)$ & $(-0.76)$ \\
\hline \multirow{2}{*}{ ANALYSTS } & & 0.0000 & 0.0000 \\
\hline & & $(-1.09)$ & $(-0.91)$ \\
\hline \# of obs. & & 4,871 & 4,871 \\
\hline Adjusted $R^{2}$ & & 0.8541 & 0.8552 \\
\hline
\end{tabular}

The dependent variable, $R E A C T$, is calculated by revised consensus of analyst forecasts - preexisting median consensus of analyst forecasts scaled by price at the beginning of the quarter.

Other detailed variable definitions are presented in the Appendix. All regressions control the industry and year fixed effect.

$*, * *$, and $* * *$ indicate two-tailed significance at the $0.10,0.05$, and 0.01 levels, respectively.

\section{The Endogeneity Issue}

I use the conservatism measures as independent variables to examine the effects of firm characteristics on analyst reaction to management disclosures. However, it is likely that the level of conservatism can be endogenously decided. Thus, I repeat the tests of conservatism using a two-stage least squares regression method. I use the firm characteristic variables that can affect the level of conservatism as instrument variables according to prior literature (Ahmed and Duellman, 2007; Krishnan and Visvanathan, 2008). In Table 7, Panel A reports the results of the second stage regression of two-stage least squares regression using the good news disclosure sample, and Panel B shows the results using the bad news disclosure sample. With the exception of certain models, the results are similar to those reported in Table 4, which support Hypotheses 2a and 2b. 
Table 7. Revision magnitude on conservatism (Two-Stage Least Squares Regression)

\begin{tabular}{|c|c|c|c|c|c|c|}
\hline \multicolumn{7}{|c|}{ Panel A. Regression results of the second stage regression (Good news disclosure, Dependent variable $=R E A C T)$} \\
\hline & \multirow{2}{*}{$\begin{array}{l}\text { Predicted } \\
\text { sign }\end{array}$} & \multicolumn{5}{|c|}{ Conservatism measures $(\mathrm{CON})$} \\
\hline & & CSCORE & CONACC & CONBM & CONAGG1 & CONAGG2 \\
\hline \multirow{2}{*}{ Intercept } & & $0.0004^{*}$ & 0.0002 & $0.0007^{* * *}$ & -0.0002 & 0.0000 \\
\hline & & $(1.85)$ & $(1.21)$ & $(3.05)$ & $(-0.69)$ & $(-0.14)$ \\
\hline \multirow{2}{*}{ GUIDE } & \multirow{2}{*}{+} & $0.3863^{* * *}$ & $0.3583^{* * *}$ & $0.3864^{* * *}$ & $0.3495^{* * *}$ & 0.3488 \\
\hline & & $(10.96)$ & $(10.62)$ & $(10.27)$ & $(9.55)$ & $(10.22)$ \\
\hline \multirow{2}{*}{$G U I D E * C O N$} & \multirow{2}{*}{+} & $-0.1640^{* * *}$ & $0.3978^{* * *}$ & $0.0323^{*}$ & 0.0030 & $0.0081^{* *}$ \\
\hline & & $(-2.76)$ & $(3.69)$ & $(1.74)$ & $(0.66)$ & $(2.48)$ \\
\hline \multirow{2}{*}{ GUIDE ${ }^{*} R E P U T A T I O N$} & \multirow{2}{*}{+} & $0.2947^{* * *}$ & $0.2909^{* * *}$ & $0.2982^{* * *}$ & $0.2955^{* * *}$ & $0.2950^{* * *}$ \\
\hline & & $(29.28)$ & $(28.60)$ & $(28.83)$ & $(29.17)$ & $(29.16)$ \\
\hline \multirow{2}{*}{ GUIDE*HORIZON } & \multirow[b]{2}{*}{+} & $-0.0277^{* * *}$ & $-0.0255^{* * *}$ & $-0.0281^{* * *}$ & $-0.0275^{* * *}$ & $-0.0275^{* * *}$ \\
\hline & & $(-4.35)$ & $(-3.98)$ & $(-4.33)$ & $(-4.29)$ & $(-4.28)$ \\
\hline \multirow{2}{*}{$G U I D E * R A N G E$} & \multirow[b]{2}{*}{ - } & $6.7450^{*}$ & $6.3692^{*}$ & $6.3580^{*}$ & $6.6208^{*}$ & $6.8596^{*}$ \\
\hline & & $(1.94)$ & $(1.83)$ & $(1.80)$ & $(1.90)$ & $(1.96)$ \\
\hline \multirow{2}{*}{ GUIDE*ANALYSTS } & \multirow{2}{*}{$?$} & 0.0045 & 0.0063 & 0.0084 & 0.0115 & 0.0059 \\
\hline & & $(0.47)$ & $(0.67)$ & $(0.89)$ & $(1.25)$ & $(0.63)$ \\
\hline \multirow{2}{*}{$C O N$} & & -0.0007 & $0.0043^{* *}$ & $0.0008^{* * *}$ & $0.0001^{* * *}$ & $0.0001^{* * * *}$ \\
\hline & & $(-1.01)$ & $(2.44)$ & $(3.32)$ & $(2.55)$ & $(2.96)$ \\
\hline \multirow{2}{*}{ REPUTATION } & & $0.0002^{* * * *}$ & $0.0002^{* * *}$ & $0.0002^{* * *}$ & $0.0002^{* * *}$ & $0.0002^{* * *}$ \\
\hline & & $(4.53)$ & $(4.75)$ & $(4.71)$ & $(4.45)$ & $(4.84)$ \\
\hline \multirow{2}{*}{ HORIZON } & & 0.0000 & 0.0000 & 0.0000 & 0.0000 & 0.0000 \\
\hline & & $(-0.73)$ & $(-0.80)$ & $(-0.74)$ & $(-0.77)$ & $(-0.67)$ \\
\hline \multirow{2}{*}{$R A N G E$} & & 0.0073 & 0.0045 & 0.0184 & 0.0063 & 0.0124 \\
\hline & & $(0.33)$ & $(0.20)$ & $(0.82)$ & $(0.28)$ & $(0.56)$ \\
\hline \multirow{2}{*}{ ANALYSTS } & & 0.0000 & 0.0000 & 0.0000 & 0.0001 & 0.0000 \\
\hline & & $(0.34)$ & $(0.67)$ & $(0.20)$ & $(1.14)$ & $(0.36)$ \\
\hline \# of obs. & & 3,346 & 3,346 & 3,346 & 3,346 & 3,346 \\
\hline Adjusted $R^{2}$ & & 0.3358 & 0.3364 & 0.3290 & 0.3325 & 0.3348 \\
\hline
\end{tabular}

The dependent variable, REACT, is calculated by revised consensus of analyst forecasts - preexisting median consensus of analyst forecasts scaled by price at the beginning of the quarter.

Instrument variables: SIZE, DEBT, CFO, CSALES, LITI, and BIG4

Other detailed variable definitions are presented in the Appendix. All regressions control the industry and year fixed effect.

$*, * *$, and $* * *$ indicate two-tailed significance at the $0.10,0.05$, and 0.01 levels, respectively.

(Table 7, Panel B continued on text page) 
(Table 7 continued)

$\underline{\text { Panel B. Regression results of the second stage regression (Bad news disclosure, Dependent variable }=R E A C T)}$

\begin{tabular}{|c|c|c|c|c|c|c|}
\hline \multirow[t]{2}{*}{ 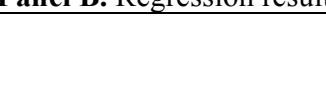 } & \multirow{2}{*}{$\begin{array}{l}\text { Predicted } \\
\text { sign }\end{array}$} & \multicolumn{5}{|c|}{ Conservatism measures (CON) } \\
\hline & & CSCORE & CONACC & CONBM & CONAGG1 & CONAGG2 \\
\hline \multirow{2}{*}{ Intercept } & & $-0.0026^{* * *}$ & $-0.0033^{* * *}$ & $-0.0021^{* * *}$ & $-0.0028^{* * *}$ & $-0.0040^{* * *}$ \\
\hline & & $(-6.67)$ & $(-9.39)$ & $(-4.50)$ & $(-5.24)$ & $(-9.41)$ \\
\hline \multirow{2}{*}{ GUIDE } & \multirow{2}{*}{+} & $0.1190^{* * *}$ & 0.0426 & $-0.1386^{* * *}$ & $0.1625^{* * *}$ & $0.0811^{*}$ \\
\hline & & $(2.65)$ & $(1.02)$ & $(-2.87)$ & $(3.69)$ & $(1.93)$ \\
\hline \multirow{2}{*}{$G U I D E * C O N$} & \multirow[b]{2}{*}{-} & $-0.2853^{* * *}$ & -0.6988 & $-0.2104^{* * *}$ & $-0.0389^{* * *}$ & $-0.0319^{* * *}$ \\
\hline & & $(-2.89)$ & $(-6.77)$ & $(-9.58)$ & $(-6.39)$ & $(-6.81)$ \\
\hline \multirow{2}{*}{ GUIDE*REPUTATION } & \multirow{2}{*}{+} & $0.2603^{* * *}$ & $0.2493^{* * *}$ & $0.2297^{* * *}$ & $0.2508^{* * *}$ & $0.2350^{* * *}$ \\
\hline & & $(25.43)$ & $(25.86)$ & $(22.49)$ & $(26.03)$ & $(23.56)$ \\
\hline \multirow{2}{*}{ GUIDE*HORIZON } & \multirow{2}{*}{+} & 0.0054 & $0.0161^{*}$ & $0.0212^{* *}$ & $0.0184^{*}$ & $0.0212^{*}$ \\
\hline & & $(0.56)$ & $(1.65)$ & $(2.10)$ & $(1.86)$ & $(2.14)$ \\
\hline \multirow{2}{*}{$G U I D E * R A N G E$} & \multirow{2}{*}{-} & $8.2291^{* * *}$ & $10.2837^{* * *}$ & $4.6583^{* * *}$ & $8.4691^{* * *}$ & $8.4307^{* * * *}$ \\
\hline & & $(4.55)$ & $(5.63)$ & $(2.48)$ & $(4.73)$ & $(4.70)$ \\
\hline \multirow{2}{*}{ GUIDE*ANALYSTS } & \multirow{2}{*}{ ? } & $0.2361^{* * *}$ & $0.2525^{* * *}$ & $0.2656^{* * *}$ & $0.2434^{* * *}$ & $0.2603^{* * *}$ \\
\hline & & $(20.08)$ & $(23.68)$ & $(23.57)$ & $(22.60)$ & $(23.88)$ \\
\hline \multirow{2}{*}{$C O N$} & & $-0.0056^{* * *}$ & -0.0033 & $0.0025^{* * *}$ & $-0.0002^{*}$ & $0.0002^{* *}$ \\
\hline & & $(-4.55)$ & $(-0.83)$ & $(4.40)$ & $(-1.68)$ & $(2.33)$ \\
\hline \multirow{2}{*}{ REPUTATION } & & $0.0006^{* * *}$ & $0.0005^{* * *}$ & $0.0005^{* * *}$ & $0.0005^{* * *}$ & $0.0005^{* * *}$ \\
\hline & & $(6.75)$ & $(6.07)$ & $(5.93)$ & $(6.20)$ & $(5.82)$ \\
\hline \multirow{2}{*}{ HORIZON } & & $0.0002^{* * *}$ & $0.0002^{* * *}$ & $0.0002^{* * *}$ & $0.0003^{* * *}$ & $0.0003^{* * *}$ \\
\hline & & $(2.92)$ & $(3.34)$ & $(3.12)$ & $(3.51)$ & $(3.55)$ \\
\hline \multirow{2}{*}{$R A N G E$} & & $-0.1487^{* * *}$ & $-0.1438^{* * *}$ & $-0.1309^{* * *}$ & $-0.1522^{* * *}$ & $-0.1442^{* * *}$ \\
\hline & & $(-4.74)$ & $(-4.64)$ & $(-4.05)$ & $(-4.92)$ & $(-4.64)$ \\
\hline \multirow{2}{*}{ ANALYSTS } & & $0.0007^{* * *}$ & $0.0009^{* * *}$ & $0.0008^{* * *}$ & $0.0009^{* * *}$ & $0.0009^{* * *}$ \\
\hline & & $(7.65)$ & $(10.70)$ & $(9.26)$ & $(10.05)$ & $(9.95)$ \\
\hline \# of obs. & & 3,309 & 3,309 & 3,309 & 3,309 & 3,309 \\
\hline Adjusted $R^{2}$ & & 0.7497 & 0.7542 & 0.7430 & 0.7535 & 0.7525 \\
\hline
\end{tabular}

The dependent variable, REACT, is calculated by revised consensus of analyst forecasts - preexisting median consensus of analyst forecasts scaled by price at the beginning of the quarter.

Instrument variables: SIZE, DEBT, CFO, CSALES, LITI, and BIG4

Other detailed variable definitions are presented in the Appendix. All regressions control the industry and year fixed effect.

$*, * *$, and $* * *$ indicate two-tailed significance at the $0.10,0.05$, and 0.01 levels, respectively.

\section{CONCLUSION}

This paper investigates the effect of firm characteristics on analyst reactions to management disclosures. Unlike prior studies, I focus on the firm characteristics rather than general management forecast characteristics or analyst-specific characteristics. Using various conservatism measures, I find that analyst reaction is greater in response to good news management disclosures from firms with a higher level of conservatism and bad news management disclosures from firms with a lower level of conservatism. This finding demonstrates that care should be taken in explaining the effect of conservatism on analyst reaction to management disclosures because the effect is different depending on the type of management disclosure using both full sample and subsample analysis. I also find that analyst reaction is greater in response to management disclosures from firms with a higher level of board independence or a lower level of managerial ownership. This implies that the corporate governance structure is a consideration of analysts in the revision of their forecasts following management disclosures. All of the results hold after controlling for general management forecast characteristics or other general variables that are likely to affect analyst reaction to management disclosures. I provide evidence that firm characteristics are considered by analysts when they reflect the management disclosures in their revisions. Therefore, my findings are consistent with the fact that analysts are interested in certain firm characteristics as a method to estimate the credibility or usefulness of management disclosures. This study extends the literature concerning financial analysts; however, it also has limitations. Future study is required to examine other effects that this study does not address, such as the effects of market reaction to management disclosure on the analyst reactions to this management disclosure. 


\section{ACKNOWLEDGEMENT}

This research was financially supported by Hansung University.

\section{AUTHOR BIOGRAPHY}

Kyunbeom Jeong, Ph.D., is an assistant professor at School of Business Administration, Hansung University in Korea. He received his Ph.D. in accounting from Korea Advanced Institute of Science and Technology (KAIST). Email: kbjeong@hansung.ac.kr

\section{REFERENCES}

Ahmed, A., Duellman, S., (2007). Accounting conservatism and board of director characteristics: an empirical analysis. Journal of Accounting and Economics, 43, 411-437.

Ajinkya, B., Bhojraj, S., \& Sengupta, P., (2005). The Association between Outside Directors, Institutional Investors and the Properties of Management Earnings Forecasts. Journal of Accounting Research, 43, 343-376.

Baginski, S., Conrad, E., \& Hassell, J., (1993). The effects of management forecast precision on equity pricing and on the assessment of earnings uncertainty. The Accounting Review, 68, 913-927.

Baik, B., \& Yi, H., (2007). Are affiliated analysts more likely than unaffiliated analysts to provide EPS forecasts that management can meet or beat? Working paper, Seoul National University, Seoul, Korea.

Basu, S., (1997). The conservatism principle and the asymmetric timeliness of earnings. Journal of Accounting and Economics, 24, 3-37.

Beasley, M., (1996). An Empirical Analysis of the Relation between the Board of Director Composition and Financial Statement Fraud. The Accounting Review, 71, 443-465.

Beaver, W., \& Ryan, S., (2000). Biases and lags in book value and their effects on the ability of the book-to-market ratio to predict book return on equity. Journal of Accounting Research, 38, 127-148.

Chen, Q., Hemmer, T., \& Zhang, Y., (2007). On the relation between conservatism in accounting standards and incentives for earnings management. Journal of Accounting Research, 45(3), 541-565.

Cotter, J., Tuna, I., \& Wysocki, P., (2006). Expectations management and beatable targets: How do analysts react to explicit earnings guidance? Contemporary Accounting Research, 23(3), 593-624.

Dugar, A., \& Nathan, S., (1995). The effect of investment banking relationships on financial analysts' earnings forecasts and investment recommendations. Contemporary Accounting Research, 12, 131-160.

Fama, E., \& Jensen, M., (1983). Separation of Ownership and Control. Journal of Law and Economics, 26, 301-325.

Feng, M., \& McVay, S., (2010). Analysts' incentives to overweight management guidance when revising their short-term earnings forecasts. The Accounting Review, 85 (5), 1617-1646.

Givoly, D., \& Hayn, C., (2000). The changing time-series properties of earnings, cash flows and accruals: has financial reporting become more conservative? Journal of Accounting and Economics, 29, 287-320.

Hassell, J., \& Lasser, D., (1988). Management earnings forecasts: Their usefulness as a source of firm specific information to security analysts. Journal of Financial Research, 11 (4), 303-319.

Hong, H., \& Kubik, J., (2003). Analyzing the analysts: Career concerns and biased earnings forecasts. The Journal of Finance 58 (1), 313-351.

Hui, K., Matsunaga, S., \& Morse, D., (2009). The impact of conservatism on management earnings forecasts. Journal of Accounting and Economics, 47, 192-207.

Khan, M., \& Watts, R., (2009). Estimation and empirical properties of a firm-year measure of accounting conservatism. Journal of Accounting and Economics, 48, 132-150.

Kim, B., \& Pevzner, M., (2010). Conditional accounting conservatism and future negative surprises: An empirical investigation. Journal of Accounting and Public Policy, 29, 311-329.

Klein, A., (2002). Audit Committee, Board of Director Characteristics and Earnings Management. Journal of Accounting and Economics, 33, 375-400.

Krishnan, G., \& Visvanathan, G., (2008). Do auditors price audit committee's expertise? The case of accounting versus nonaccounting financial experts, Journal of Accounting, Auditing and Finance, 24, 115-144.

LaFond, R., \& Watts, R., (2008). The information role of conservatism. The Accounting Review, 83, 447-478.

Lim, T., (2001). Rationality and analysts' forecast bias. The Journal of Finance, 56 (1), 369-385.

Lin, H., \& McNichols, M., (1998). Underwriting relationships, analysts' earnings forecasts and investment recommendations. Journal of Accounting and Economics, 25, 101-128.

Morck, R., Shleifer, A., \& Vishny, W., (1988). Management ownership and market valuation: An empirical analysis. Journal of Financial Economics, 20, 293-315. 
Pae, J., \& Thornton, D., (2010). Association between accounting conservatism and analysts' forecast inefficiency. Asia-Pacific Journal of Financial Studies, 39 (2), 171-197.

Richardson, S., Sloan, R., Soliman, M., \& Tuna, I., (2005). Accrual reliability, earnings persistence and stock prices. Journal of Accounting and Economics, 39, 437-485.

Sengupta, P., (2004). Disclosure Timing: Determinants of the Quarterly Earnings Release Dates. Journal of Accounting and Public Policy, 23, 457-482.

Shleifer, A., \& Vishny, W., (1986). Large Shareholders and Corporate Control. Journal of Political Economy, 94, 461-488.

Tan, H., Libby, R., \& Hunton, J., (2010). When Do Analysts Adjust for Biases in Management Guidance? Effects of Guidance Track Record and Analysts' Incentives. Contemporary Accounting Research, 27 (1), 187-208.

Watts, R., (2003). Conservatism in accounting part I: explanations and implications. Accounting Horizon, 17, $207-221$.

Williams, P., (1996). The relation between a prior earnings forecast by management and analyst response to a current management forecast. The Accounting Review, 71 (1), 103-113. 


\section{APPENDIX 1}

The variable definitions

\begin{tabular}{|c|c|}
\hline Variable name & Definition \\
\hline GUIDE & $\begin{array}{l}\text { Management earnings forecast - the preexisting median consensus of analyst forecasts, scaled by price at } \\
\text { the beginning of the quarter (where the preexisting consensus analyst forecast is the last revised consensus } \\
\text { within } 30 \text { days prior to management disclosure). }\end{array}$ \\
\hline REACT & $\begin{array}{l}\text { Revised consensus of analyst forecasts - the preexisting median consensus of analyst forecasts, scaled by } \\
\text { price at the beginning of the quarter (where the revised consensus is the last revised consensus available } \\
\text { in the } 15 \text { days following the management disclosure, and if there is no revision, the preexisting forecast } \\
\text { is used as the revised consensus) }\end{array}$ \\
\hline CSCORE & Conservatism measure in Khan and Watts (2009). Detailed procedures are explained in Section 3.2.2. \\
\hline CONACC & $\begin{array}{l}\text { Conservatism measure using accruals from Givoly and Hayn (2000), calculated by (income before } \\
\text { extraordinary items - cash flows from operations + depreciation expense) divided by average total assets. }\end{array}$ \\
\hline CONBM & $\begin{array}{l}\text { Conservatism measure from Beaver and Ryan (2000), calculated by book-to-market ratio multiplied by } \\
\text { negative one }(-1) \text {. }\end{array}$ \\
\hline CONAGG1 & Average rank of CSCORE, CONACC, and CONBM. \\
\hline CONAGG2 & Average rank of CONACC and CONBM. \\
\hline CEO_OWN & The percentage of total shares held by the CEO to total outstanding shares. \\
\hline TOP_OWN & The percentage of total shares held by the top-five executives to total outstanding \\
\hline B_INDEP & The percentage of directors that are independent in the board of directors. \\
\hline AC_INDEP & The percentage of directors that are independent in the audit committee. \\
\hline DOWN & $\begin{array}{l}\text { Equal to } 1 \text { if the manager's disclosure is below the preexisting consensus of analyst forecasts and } 0 \\
\text { otherwise. }\end{array}$ \\
\hline REPUTATION & $\begin{array}{l}\text { The mean value of management disclosure accuracy over three years centered on year t, where the } \\
\text { accuracy is equal to } 1,0 \text {, and }-1 \text { if the absolute value of the management forecast error is less than, equal } \\
\text { to, and greater than the preexisting analyst forecast error. }\end{array}$ \\
\hline HORIZON & $\begin{array}{l}\text { The log of the number of days between the release of a management forecast and the actual earnings } \\
\text { announcement. }\end{array}$ \\
\hline RANGE & $\begin{array}{l}\text { The range of the management forecast scaled by the stock price at the beginning of the quarter for a range } \\
\text { forecast, and } 0 \text { for a point forecast. }\end{array}$ \\
\hline ANALYSTS & The log of the total number of analyst forecasts used in consensus following a management forecast. \\
\hline
\end{tabular}




\section{NOTES}

